\title{
Evaluation of the Cytocompatibility of Mixed Bovine Bone
}

\author{
Esther Rieko TAKAMORI ${ }^{1}$ \\ Eduardo Aleixo FIGUEIRA ${ }^{1}$ \\ Rumio TAGA ${ }^{1}$ \\ Mari Cleide SOGAYAR ${ }^{2,3}$ \\ José Mauro GRANJEIRO ${ }^{3,4}$ \\ ${ }^{1}$ Department of Biological Sciences, School of Dentistry of Bauru, University of São Paulo, Bauru, SP, Brazil \\ ${ }^{2}$ Department of Biochemistry, Institute of Chemistry, University of São Paulo, São Paulo, SP, Brazil \\ ${ }^{3}$ Cell and Molecular Therapy Center, University of São Paulo, São Paulo, SP, Brazil \\ ${ }^{4}$ Department of Cell and Molecular Biology, Fluminense Federal University, Niterói, RJ, Brazil
}

\begin{abstract}
Treatment of bovine bone with peroxides and chaotropic agents aims to obtain an acellular bone matrix that is able to maintain the collagen-apatite complex and a higher mechanical resistance, a mixed biomaterial hereby named mixed bovine bone (MBB). The purpose of this study was to evaluate the cytocompatibility of MBB and cell-MBB interaction. Cell morphology, number of viable cells, ability to reduce methyltetrazolium and to incorporate neutral red upon exposure to different concentrations of the hydrosoluble extract of MBB were assessed in Balb-c 3T3 cells according to ISO 10993-5 standard. The interaction between cells and MBB surface was evaluated by scanning electron microscopy. The water-soluble MBB extracts were cytotoxic and led to cell death possibly due to its effect on mitochondrial function and membrane permeability. Cells plated directly onto the MBB did not survive, although after dialysis and material conditioning in DMEM $+10 \% \mathrm{FCS}$, the cells adhered and proliferated onto the material. It may be concluded that, in vitro, water-soluble MBB extracts were cytotoxic. Nevertheless, MBB cytotoxic effect was reverted by dialysis resulting in a material that is suitable for cell based-therapy in the bioengineering field.
\end{abstract}

Key Words: biocompatibility, bone graft, cell viability, cytotoxicity, fibroblast.

\section{INTRODUCTION}

Xenografts constitute an option to autogenous grafts for treatment of bone loss, and may also be used as carriers of cells or growth factors in tissue engineering (1) or barriers to separate the adjacent tissues from the surgical site improving bone regeneration (2). Thus, bovine bone may be processed through adequate techniques for production of different biomaterials (Gen$\mathrm{Ox}^{\circledR}$, Baumer S.A., Mogi Mirim, SP, Brazil; Endobon ${ }^{\circledR}$, MerckKgaA, Merck Biomaterial Darmstadt; KeilBone ${ }^{\mathrm{TM}}$, Braun Milsungen, Milsungen, Germany; Bio-Oss ${ }^{\mathrm{TM}}$, Geistlich Pharma, Wolhusen, Switzerland; and Surgibone $^{\mathrm{TM}}$, Unilab Surgibone, Mississauga, Ontario,
Canada) with physicochemical properties similar to those of human bone. Moreover, the source is abundant and the risk of disease transmission is minimum (3).

Bone is primarily constituted of type I collagen and hydroxyapatite. However, the physicochemical processes normally employed for obtaining the xenogenic biomaterial preserve only the organic component by demineralization or the anorganic phase by thermal deproteinization. Sintering processes yield virtually nonabsorbable biomaterial (4). In another study, BMPs (bone morphogenetic proteins) obtained from the bovine fetal cortical bone were adsorbed to microcrogranular hidroxyapatite prepared from chemical reaction between calcium chloride $\left(\mathrm{CaCl}_{2}\right)$ and sodium phosphate

Correspondence: Prof. Dr. José Mauro Granjeiro, Departamento de Biologia Celular e Molecular, Instituto de Biologia, Universidade Federal Fluminense, Outeiro de São João Baptista, S/N, Campus do Valonguinho, Centro, 24020-150 Niterói, RJ, Brasil. Tel: +55-21-26292324. Fax: +55-21-3701-1617. e-mail: jmgranjeiro@vm.uff.br 
$\left(\mathrm{Na}_{2} \mathrm{HPO}_{4}\right)$ with posterior thermal treatment with sodium hydroxide and phosphate buffer (5).

Mechanical and chemical processing of bovine bone using organic compounds, such as peroxides and chaotropic agents, yelds a mixed biomaterial here called mixed bovine bone (MBB). The potential advantage of maintenance of collagen and hydroxyapatite is the improvement in structural characteristics of the biomaterial, such as resilience and mechanical resistance. However, it is important that, upon these physicochemical treatments, no cytotoxic or immunogenic residue lies on the material, i.e., it should be biocompatible (6).

The first level of tests for evaluation of biocompatibility is the determination of in vitro cytotoxicity (7). It should be noted that cytotoxicity assays may be used at the stage of product development, when it is intended to establish the best proportion of the components of a biomaterial or when an existing material is modified, normally performed by comparison to other biomaterials with similar applications. Another test for in vitro evaluation of biocompatibility with cultured cells is the interaction between the cells and the implant surface, which may be evaluated by light microscopy and/or by scanning electron microscopy, analyzing cell morphology and adhesion, number of cells and cell proliferation potential when plated onto the tested material $(8,9)$.

The purpose of this study was to evaluate the cytocompatibility of MBB and cell-MBB interaction.

\section{MATERIAL AND METHODS}

\section{Material}

Bovine bones were obtained from a local slaughterhouse, submitted to mechanical and chemical cleaning by treatment with peroxides and chaotropic agents, neutralized in neutral phosphate buffer and lyophilized. Granules (250-1000 $\mu \mathrm{m})$ were obtained by milling and sterilized by gamma radiation ( $25 \mathrm{KGy}$ ).

\section{Preparation of the Extract}

Crude extracts of MBB were obtained in Dulbecco's modified Eagle's medium(DMEM) (Cultilab, Campinas, SP, Brazil) without fetal calf serum (FCS) in a concentration of $100 \mathrm{mg} / \mathrm{mL}$ (material/DMEM culture medium) for $24 \mathrm{~h}$ at $37^{\circ} \mathrm{C}$ in $5 \% \mathrm{CO}_{2}$ atmosphere, following the guidelines of ISO standard 10993-12(10). Grade 2 titanium was used as a negative control and phenol $0.2 \%$ in saline as positive control, according to ISO 10993-5 standard (7). From the crude extract (100 mg/ $\mathrm{mL}$ ) serial dilutions were obtained, namely: $75,50,25,20$, 4, 2, $1,0.2,0.1 \mathrm{mg} / \mathrm{mL}$.

\section{Cell Culture}

Balb/c 3T3 fibroblasts (clone A31) (American Type Culture Collection) were cultured in DMEM containing $\mathrm{NaHCO}_{3}(1.2 \mathrm{~g} / \mathrm{L})$, ampicillin $(0.025 \mathrm{~g} / \mathrm{L})$, streptomycin $(0.1 \mathrm{~g} / \mathrm{L})$ supplemented with $10 \%$ FCS (Cultilab) at $37^{\circ} \mathrm{C}$ in $5 \% \mathrm{CO}_{2}$ atmosphere.

\section{Cytotoxicity Assays}

The cytotoxicity assays were performed using 24-well plates, by plating Balb/c 3T3 cells at the density of $3 \times 10^{4}$ cells/well. After 48 -h incubation, the cultures were treated with different concentrations of bone extracts $(0.1-100 \mathrm{mg} / \mathrm{mL})$ in DMEM $+10 \%$ FCS. After $24 \mathrm{~h}$, the culture medium containing the extract was removed and the cells were washed with PBS-A, treated with trypsin for cell counting or for determination of reduction of 3-[4,5-dimethylthiazol-2-yl]-2,5diphenyltetrazolium bromide (MTT) or incorporation of neutral red (NR). All assays were performed in triplicates in two independent experiments.

\section{Cell Counting}

The cells were counted in a Neubauer chamber. The number of cells corresponding to each extract concentration was calculated relative to the untreated control group, considered as $100 \%$. Lethal dose 50 (LD50), defined as the concentration necessary to kill $50 \%$ of the relative cell number, was calculated by extrapolation of the data on the dose response curve.

\section{Reduction of MTT}

Cell viability was analyzed following the technique described by Mosmann (11), in which the MTT is reduced to formazan blue only by viable mitochondriae. After treatment with the different concentrations of the extracts, the cultures were incubated with $0.5 \mathrm{mg}$ of 
MTT/mL of DMEM. The mitochondrial function was then calculated relative to the control group (without any extract), considered as $100 \%$. LD50, defined as the concentration necessary to impair in 50\% the reduction of MTT to formazan blue, was calculated by extrapolation of the data on the dose response curve.

\section{Incorporation of Neutral Red (NR)}

This assay is based on the ability of viable cell lysosomes to absorb the NR dye. After treatment with the different concentrations of bone extracts, the cells were incubated with the NR dye $(50 \mathrm{mg} / \mathrm{mL}$ of DMEM), following the technique described by Borenfreund and Puener (12). Cell viability corresponding to each extract concentration was calculated relative to the control group (no extract), considered as $100 \%$. Lethal dose 50 (LD50), defined as the concentration necessary to impair in 50\% the neutral red uptake, was calculated by data extrapolation on the dose response curve.

\section{Morphologic Analysis}

Light Microscopy - $3 \times 10^{4}$ cells were plated onto glass coverslips placed in 24-well plates. After 48-h incubation, the cultures were treated with different dilutions of MBB extract in DMEM $+10 \%$ FCS for 24 $\mathrm{h}$. The cells were then fixed in $3.7 \%$ formaldehyde in 0.2 $\mathrm{M}$ phosphate buffer ( $\mathrm{pH}$ 7.2) and stained with hematoxylin and eosin (HE).

Scanning Electron Microscopy (SEM) - Particles of MBB were adhered to glass coverslips coated with three-dimensional rat tail hydrated type I collagen (13) to avoid displacement of the MBB granules. Balb/c 3T3 fibroblasts (clone A31) were plated onto the $\mathrm{MBB}$ at the density of $5 \times 10^{4}$ cells/coverslips. At periods of 24,72 and $120 \mathrm{~h}$ after plating, the cells were fixed with modified Karnovsky's solution and post-fixed with $1 \%$ osmium tetroxide in $0.05 \mathrm{M}$ cacodylate buffer, $\mathrm{pH} 7.2$, for $1 \mathrm{~h}$ at room temperature. The samples were washed with distilled water, dehydrated in increasing solutions of ethanol and critical point drying, metallized with gold and analyzed under scanning electron microscope Zeiss ${ }^{\circledR}$ (NAP/MEPA - Dr. Elliot Kitajima, ESALQ-USP).

\section{Statistical Analysis}

The quantitative data obtained in the cytotoxicity assays were submitted to ANOVA and Tukey's test at a probability level of 5\% $\left(\right.$ Instat $^{\circledR}$ Graph Pad Software; GraphPad Software Inc., San Diego, CA, USA).

\section{RESULTS}

\section{Cytotoxicity Analysis}

Figure 1A shows that the crude MBB extract $(100 \mathrm{mg} / \mathrm{mL})$ led to reduction of $69.2 \%$ in cell number. Based on data in Figure 1, it can be calculated that 50\% of the cells died at around $54 \mathrm{mg} / \mathrm{mL}$ of MBB extract. The mechanisms involved in this cell death could be better addressed by investigating cell ability in reducing MTT to formazan blue (Fig. 1B) and uptaking neutral red (Fig. 1C) as a function of extract concentrations. The pure MBB extracts decreased the mitochondrial function by nearly $90 \%$ while in the presence of $75 \mathrm{mg} /$ $\mathrm{mL}$ of MBB extract cell ability to reduce MTT decreased to nearly $30 \%(\mathrm{p}<0.01)$ (Fig. 1B). NR uptake droped to half at $95.8 \mathrm{mg} / \mathrm{mL}$ of MBB extract $(\mathrm{p}<0.01)$ (Fig. 1C). The dose that decreased cell number in $50 \%$, formazan blue production and neutral red uptake were, respectively, 53.9, 62.7, and $95.8 \mathrm{mg} / \mathrm{mL}$ (extrapolation from data points in Fig. 1).

\section{Morphologic Analysis of the Effect of MBB Extracts in Balb/c 3 T3 Fibroblasts}

Under light microscopy it was observed that 75 $\mathrm{mg} / \mathrm{mL}$ of MBB extract yielded a marked reduction in cell density and alterations in cell morphology, with reduction in the cytoplasmic volume, fusiform aspect, reduction of intercellular contacts and nuclear alterations, such as condensation and reduction in volume, when compared to the control (untreated) group, with some cells also presenting picnotic nuclei, suggesting apoptosis (Fig. 2A). The crude extract caused a greater reduction in cell density and a higher frequency of picnotic nuclei, suggesting apoptosis (Fig. 2B).

SEM analysis showed the interaction between the cells and material surface. Initially, the cells were plated directly on the MBB particles. Also, there was intensive cell death without fibroblast adhesion onto material surface; the few cells adhered to plastic substrate below the particles, underwent cytolysis.

In order to investigate whether the deleterious effect observed was related to the material's physico- 

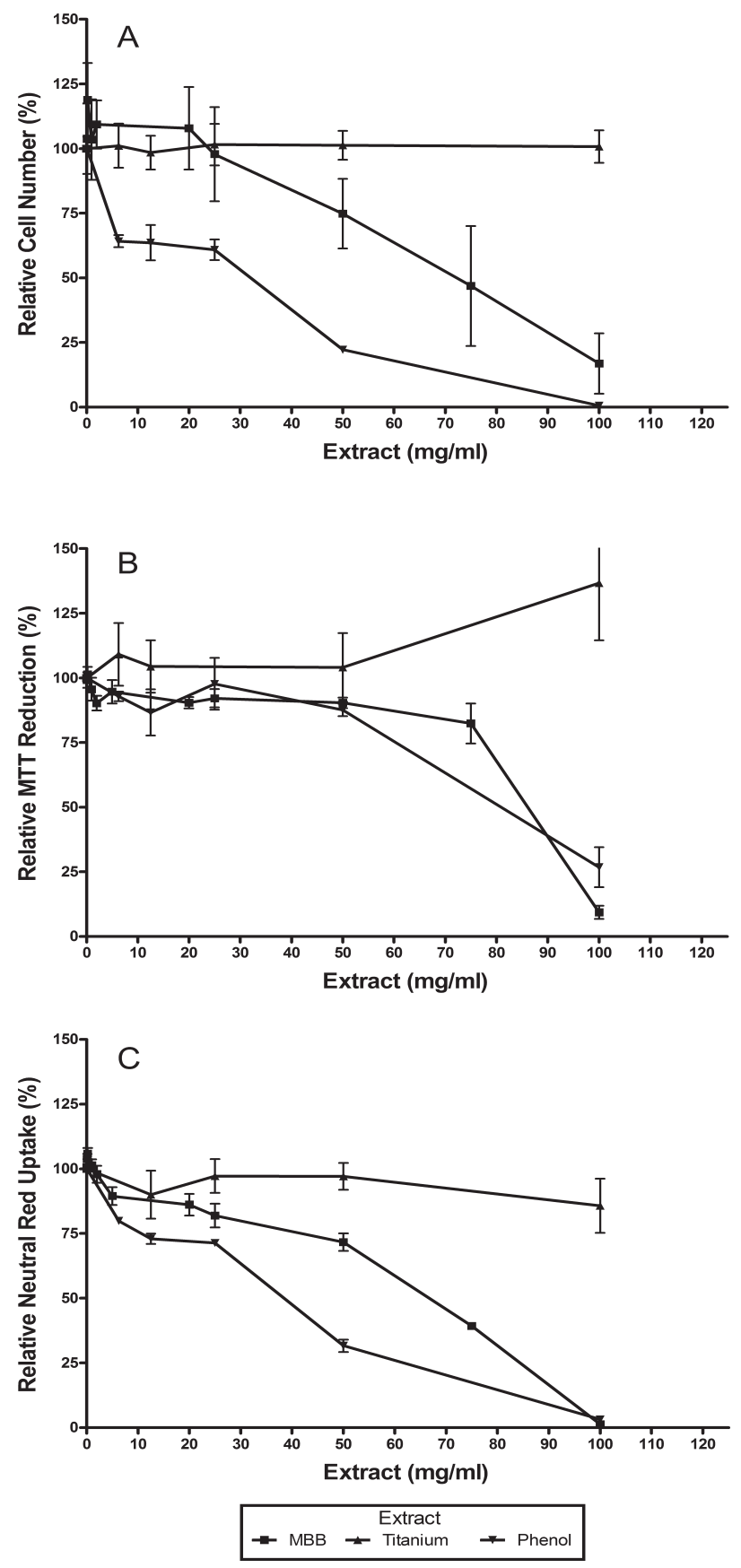

Figure 1. Graphic representation of the effect of MBB extract concentration on the number of cells (A), MTT reduction (B) and neutral red uptake $(C)$. Negative control - Titanium extract, Positive control-Phenol 0.2\% solution. Cells Balb/c 3T3 (3x10 $)$ were treated with different concentrations of extract of mixed bovine bone (MBB) in DMEM plus $10 \% \mathrm{FCS}$ during $24 \mathrm{~h}, 37^{\circ} \mathrm{C}$, $5 \% \mathrm{CO}_{2}$. The results are expressed as percentage in relation to the control (without extract), considered as $100 \%$. The data represent the mean of two independent studies in triplicate. The bars represent the standard deviation of the mean. chemical characteristics or to the presence of toxic residues on its surface, the MBB granules were subjected to dialysis against sterile deionized water and conditioned in DMEM + 10\% FCS during $72 \mathrm{~h}$. Despite the change in DMEM color (from red to yellow), no $\mathrm{pH}$ changes occurred. The cells were once again plated onto material surface. Adhered cells emitting cytoplasmic extensions were observed $24 \mathrm{~h}$ after plating (Fig. 3A). After $72 \mathrm{~h}$, the fibroblasts exhibited normal morphology and higher density than in the previous period (Fig. 3B). Cell density still increased onto material surface after $120 \mathrm{~h}$ showing contact between cells and mitoses (Figs. 3 C-D).

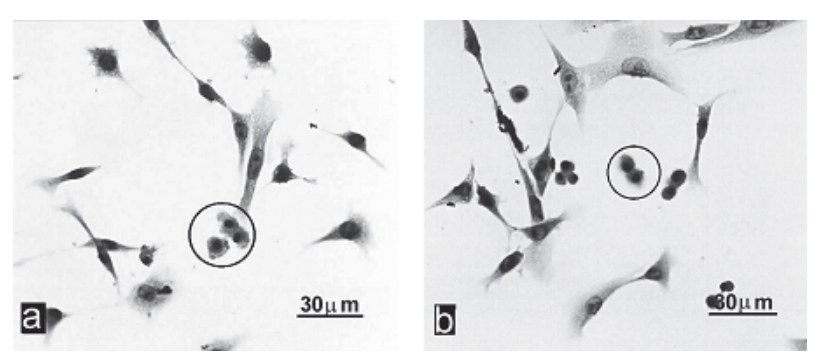

Figure 2. Photomicrograph of Balb/c 3 T3 fibroblasts cultured on glass slab after 24-h treatment with MBB extract dilutions: 75 (A) and $100 \mathrm{mg} / \mathrm{mL}$ (B). In the circles, cells show morphological aspect suggesting apoptosis.
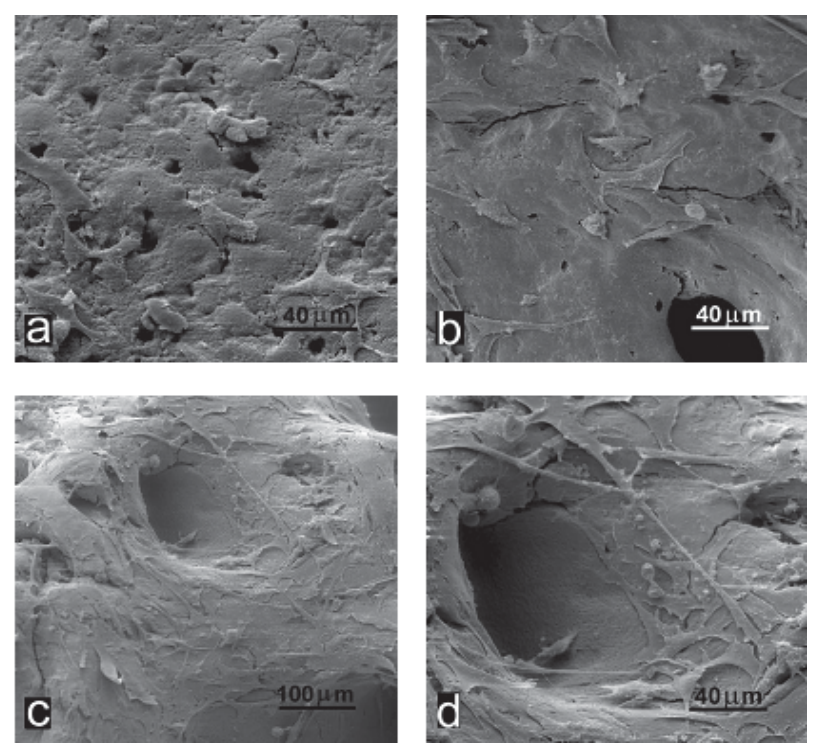

Figure 3. SEM micrograph of Balb/c 3T3 fibroblasts cultured on MBB, adhered to the glass slab with rat tail collagen: after $24 \mathrm{~h}$ (A), $72 \mathrm{~h}(\mathrm{~B})$ and $120 \mathrm{~h}$ (C and D). 


\section{DISCUSSION}

Treatment of bovine bone xenografts should be performed to eliminate whole cells, membrane fragments, debris, lipids and proteins, which are potentially able to activate the receptor's defense systems, ensuring its biocompatibility. The chemical processes employed during production of these materials potentially are of risk if toxic residues persist exacerbating the inflammatory process.

MBB is a potential bone graft material to aid bone repair because it combines resistance and resilience. However, its cytotoxicity and biocompatibility is yet to be determined in vitro (6).

As prepared, MBB promoted cell death by compromising mitochondrial activity and cell membrane integrity. Serial dilutions of the crude extracts reduced the deleterious effects on Balb/c 3T3 cells, indicating the existence of hydrosoluble factors triggering these effects. In this context, it should be highlighted that the cytotoxicity displayed by some glass ceramics used as bone substitutes has been associated with the release of components from the material to the extract (14). Two different blends of corn-starch, starch/ethylene vinyl alcohol (SEVA-C) and starch/cellulose acetate (SCA) and their respective composites with hydroxyapatite (HA) were assessed by cytotoxicity and cell adhesion tests.

In the present study, the cytotoxic effect of MBB was reverted by dialysis against deionized water and conditioning with culture medium plus FCS, strengthening the hypothesis that removal of water-soluble residue does not impair adhesive and proliferative properties for fibroblasts. Casabona et al. (15) adopted similar procedures, washing hydroxyapatite blocks before plating cells on it and, later on, introducing them into animals.

In addition to the removal of toxic residues, conditioning MBB with DMEM $+10 \%$ FCS may also have allowed the adsorption of FCS proteins, especially fibronectin, which is important in the mechanisms of cell adhesion. According to Boyan et al. (16), before introduction into the receptor, biomaterials should be conditioned by the components of the fluid in which it will be immersed, either blood serum, saliva, gingival fluid or cell culture medium. Moreover, the nature of the conditioning biomolecules and their orientation on the material surface directly influence cell recruitment, adhesion, proliferation and differentiation (16).

The effect of the biomaterial surface on cell adhesion, proliferation and differentiation has been clearly demonstrated in the literature (17). However, little is known about the molecular mechanisms involved in the interactions between cells and this biomaterial. Systematic studies will be required to better understand such events.

Rodrigues et al. (18), attempting to characterize biomaterials composed of hydroxyapatite (sinterized) and collagen, both of bovine origin and mixed in different proportions, evaluated cytotoxicity using an indirect contact method with agar, by plating $\mathrm{C} 3 \mathrm{H} / \mathrm{NA}$ mouse fibroblast strains (Rio de Janeiro cell bank, UFRJ, Brazil), and did not observe cytotoxicity. Cell adhesion analysis by SEM showed in that study that human osteoblasts were scarce after 4 days of culture, increasing significantly after 11 days. It is noteworthy that the tested biomaterial was treated with human serum, establishing a protein-material interface, possibly increasing cell proliferation (18).

SEM analysis of the present work revealed a pattern of cell adhesion, proliferation and spreading on the dialyzed and FCS-conditioned MBB very similar to that reported by Açil et al. (1) for Bio-Oss, an anorganic xenograft. Hofman et al. (19) compared Laddec, a mixed bovine xenograft, to Bio-Oss and found a good interaction between osteoblasts and Laddec ${ }^{\circledR}$, higher expression of alkaline phosphatase and presence of mineralization nodules in contact with Laddec $^{\circledR}$, when compared to Bio-Oss ${ }^{\circledR}$. It should be mentioned that during Laddec $^{\circledR}$ processing, in addition to chemical treatments, high pressure washing was also performed by these authors, possibly allowing better removal of toxic residues.

Even though evaluation of cytotoxicity is very important for a preliminary analysis of biomaterials, this is not the sole determinant in biocompatibility assessment. In vivo, homeostasis could overcome an initial toxicity induced by soluble residues due to the dilution and buffering effect of body fluids. In fact, in vivo studies have demonstrated that several commercially available xenogenic biomaterials are biocompatible and osteoconductive when properly processed (20)

The findings of the present results showed that, in vitro, water-soluble MBB extracts were cytotoxic leading to cell death possibly due to their effect on mitochondrial function and membrane permeability. The cytotoxic effect was reverted by dialysis resulting in a material suitable forcell based therapy in the bioengineering field.

\section{RESUMO}

O tratamento do osso bovino com peróxidos e agentes caotrópicos 
visa à obtenção de uma matriz óssea acelular, com manutenção do complexo colágeno-apatita e maior resistência mecânica, denominada osso bovino misto (OBM). O objetivo desse estudo foi avaliar a citocompatitiblidade do osso bovino misto e a interação célula-OBM. Células Balb-c 3T3 foram tratadas com diferentes concentrações do extrato hidrossolúvel do $\mathrm{OBM}(0,1 \mathrm{~g}$ por mililitro de meio de cultura sem soro). Foram avaliadas a morfologia e número de células, a capacidade de redução do metil tetrazol e a incorporação de vermelho neutro, de acordo com o padrão ISO 10993-5. A interação células-OBM foi estudada por microscopia eletrônica de varredura. Os extratos hidrosolúveis do OBM levaram à morte celular, possivelmente devido à redução da função mitocondrial e aumento da permeabilidade de membrana. Células plaqueadas diretamente sobre o OBM não sobreviveram. Entretanto, após diálise e condicionamento com DMEM $+10 \%$ de soro fetal bovino, as células aderiram e proliferaram sobre o material. Com base nos resultados obtidos, concluiu-se que o OBMé citotóxico. A citotoxicidade foi revertida por diálise resultando em um material adequado para terapia celular no campo da bioengenharia.

\section{ACKNOWLEDGEMENTS}

The authors acknowledge the Brazilian Funding Agencies that supported this research: FAPESP (Grant \#01/10707-7 and 99/ 06460-4), CNPq (Grant \#350084/03-3; \#475721/2003-9, \#505350/04-1), FINEP (\#01.04.0469.00) PRP-USP, CAPES (Fellowship to the first author).

\section{REFERENCES}

1. Açil Y, Terheyden H, Dunsche A, Fleiner B, Jepsen S. Threedimensional cultivation of human osteoblast-like cells on highly porous natural bone mineral. J Biomed Mater Res 2000;51:703-710.

2. Oliveira RC, Menezes R, Cestari TM, Taga EM, Taga R, Buzalaf MAR, Granjeiro JM. Tissue response to a membrane of demineralized bovine cortical bone implanted in the subcutaneous tissue of rats. Braz Dent J 2004;15:3-8.

3. Aichelmann-Reidy ME, Yukna RA. Bone Replacement Grafts. The bone substitutes. Dent Clin North Am 1998;42:491-503.

4. Sicca CM, Oliveira RC, Silva TL, Cestari TM, Oliveira DT, Buzalaf MAR, Taga R, Taga EM, Granjeiro JM, Kina JR. Microscopic and biochemical analysis of the cellular response to cortical bovine grafts implanted in rat subcutaneous. Effect of particle sizes. J App Oral Sci 2000;8:1-10.

5. Ferreira GR, Cestari TM, Granjeiro JM, Taga R. Lack of repair of rat skull critical size defect treated with bovine morphometric protein bound to microgranular bioabsorbable hydroxyapatite. Braz Dent J 2004;15:175-180.
6. Wataha JC. Principles of biocompatibility for dental practitioners. J Prosthet Dent 2001;86:203-209.

7. ISO 10993-5. Biological evaluation of medical devices. Part 5: Tests for cytotoxicity: In vitro methods. International Organization for Standardization. Geneva; 1999.

8. Anselme K. Osteoblast adhesion on biomaterials. Biomaterials 2000;21:667-681.

9. Bogdanski D, Koller M, Muller D, Muhr G, Bram M, Buchkremer HP, Stover D, Choi J, Epple M. Easy assessment of the biocompatibility of Ni-Ti alloys by in vitro cell culture experiments on a functionally graded Ni-NiTi-Ti material. Biomaterials 2002;23:4549-4555.

10. ISO 10993-12. Biological evaluation of medical devices. Part 12: Sample preparation and reference materials. International Organization for Standardization. Geneva; 1996.

11. Mosmann T. Rapid colorimetric assay for cellular growth and survival: application to proliferation and cytotoxicity assays. J Immunol Methods 1983;65:55-63.

12. Borenfreund E, Puener JA. A simple quantitative procedure using monolayer cultures for cytotoxicity assays (HTD/NR 90). J Tissue Cult Meth 1984;9:7-9.

13. Maria SS, Wada ML. Cytochemical analysis of Vero cells on type I collagen gels in long-term culture. In Vitro Cell Dev Biol Anim 1997;33:748-750.

14. Ignatius AA, Schmidt C, Kaspar D, Claes LE. In vitro biocompatibility of resorbable experimental glass ceramics for bone substitutes. J Biomed Mater Res 2001;55:285-294.

15. Casabona F, Martin I, Muraglia A, Berrino P, Santi P, Cancedda R, Quarto R Prefabricated engineered bone flaps: an experimental model of tissue reconstruction in plastic surgery. Plast Reconstr Surg 1998;101:577-581.

16. Boyan BD, Hummert TW, Dean DD, Schwartz Z. Role of material surfaces in regulating bone and cartilage cell response. Biomaterials 1996;17:137-146.

17. Wiedmann-Al-Ahmad M, Gutwald R, Gellrich NC, Hubner U, Schmelzeisen R. Search for ideal biomaterials to cultivate human osteoblast-like cells for reconstructive surgery. J Mater Sci Mater Med 2005;16:57- 66.

18. Rodrigues CV, Serricella P, Linhares AB, Guerds RM, Borojevic R, Rossi MA, Duarte ME, Farina M. Characterization of a bovine collagen-hydroxyapatite composite scaffold for bone tissue engineering. Biomaterials 2003;24:49874997.

19. Hofman S, Sidqui M, Abensur D, Valentini P, Missika P. Effects of Laddec on the formation of calcified bone matrix in rat calvariae cells culture. Biomaterials 1999;20:11551166.

20. Zambuzzi WF, Oliveira RC, Pereira FL, Cestari TM, Taga R, Granjeiro JM. Rat subcutaneous tissue response to macrogranular porous anorganic bovine gone graft. Braz Dent J 2006; 17:274-280. 